\title{
離乳後の未成体期ラットにおける情動反応性の一時的低 下現象一ランウェイ・テストを指標とした検討
}

\section{東海女子大学 宮本邦雄}

A temporary reduction of emotional reactivity in postweaning, prejuvenile rats: Examination by the Runway Test Kunio Miyamoto (Department of Psychology, Faculty of Letters, Tokai Women's College, Nakakirino-cho, Kakamigahara 504)

Developmental change of emotional reactivity in Wistar rats was investigated by two experiments using the Runway Test. Rats were tested at 20,30, 40,60, and 90 days of age for three succesive days. First, a cross-sectional comparison of behavior in the Runway Test showed that 30-day-old rats were faster to enter the runway region, faster to reach the end section, and traversed more sections than other age groups. Rats at 60 and 90 days of age defecated more bolles and urinated more. Second, longitudinal comparisons showed that the ambulation of $30-$ and 40-day-old rats increased gradually over test days, suggesting lowered emotional reactivity. But 60- and 90-day-old rats showed asymptotic level of ambulation and no increase between days and less defecation. These results suggested that postweaning prejuvenile rats showed a temporary reduction of emotional reactivity in novel environments. Also, their emotional reactivity elevated gradually, and remained stable in each individual level.

Key words: behavioral development, emotional reactivity, Runway Test, rats.

ラットやマウスの觢歯動物が新奇事態で示す行動様 式の個体差をもとに，情動反応性（emotional reactivity）という概念が用いられてきた。新奇場面に おいて，すくみ反応を示すことなく活動的な探索を続 ける個体を低情動であるといい, すくみ反応が多く排 便や排尿を頻発し, 活動量の低下する個体を高情動で あるという。この情動反応性は個体のもつ基本的な特 性であり, 回避学習などの学習行動や社会的行動など の個体差に大きく寄与していることが報告されてきた (Annen, 1985; Iso, Brush, Fujii, \& Shimazaki, 1988; Satinder, 1981).

しかし情動反応性は生後初期から固定的なものでは なく, 発達に伴い変化する可能性がある.たとえば, 中村・阿部・藤田（1978）はラットの貯蔵行動が情動 反応性によって強く規定されると報告したが，その発 達的変化を調べた宮本（1993）によると, 離乳後の 30-35 日齢で貯蔵レベルは低下し，また他の日齢と 異なり日間増加を示さなかった。これは, 新奇場面に おける情動的反応が減少し, 走路上での搨食反応が増 加したためであると考えられる。

これまでラットを対象とした行動発達研究では, 移 動行動や社会的行動などが取り上げられてきたが, 成 体型の完成された行動パターンに至るまでの発達過程 やその規定因を探求することが主たる目的であった。 そこには, 発達途上にある未成体の行動は完成された
成体型行動の前駆形態であるという前提がある。しか し近年, それぞれの発達段階は完全な形態 (a form of completeness）をなしており，幼若な生体はそれぞれ の発達段階の環境に適応的な存在であるという, 個体 発生的適応 (ontogenetic adaptation) の概念が提唱さ れている (Alberts, 1987)。こうした見地から, 種々 の行動の基底にある情動反応性が発達的にどのように 変化するのかを検討する必要があると思われる。

ラットやマウスの情動反応性を反映すると考えられ てきたオープン・フィールド・テストを用いた発達研 究は, 活動量を指標としたものが多い.その一般的な 結果としては, 離乳後の未成体期ラットは“過活動 的”である (Spear \& Brake, 1983; Lanier \& Issacson, 1977; Campbell \& Marby, 1972).たとえば, 30-40 日齢ラットは，それ以降の日歯に比べて移動量が多 く，それは離乳前における過活動期の15日歯と同程 度のレベルであり，他の日歯と異なり日間減少も示さ ない(Bronstein, 1972; 1973).

しかし，これらと一致しない報告も多い.まず Valle \& Bols（1976）によると, 30 日歯の雌ラットは 120 日齢よりも移動量や立ち上がりが少なく, 雄には 差がみられない.また Bauer \& Duncan（1975）は， 33 日齢ラットの活動量には成体と有意な差がみられ ないと報告した.さらに, Satinder (1981) は, オー プン・フィールド・テストの排便量をもとにした選択 
交配系（MNR 系ラットと MR 系ラット）掠よびそれ らの交雑系におけるオープン・フィールド行動の発達 を検討した．排便量では，他の系統と比べ少ない MNR 系は 35 日齢で多いが，MR 系は日齢に伴う増 加傾向を示す．移動量については，MR 系は 35 日齢 で増加するが，MNR 系と交雑系は高いレベルにあり 変化を示さない.

このようにオープン・フィールド・テストを用いた 結果は一貫したものではない。これは一部の実験で Within subject のテストが用いられていることによる のかもしれない. 一般に，オープン・フィールド・テ ストでは繰り返しにより慣れが生じ，活動量が低下す る.つまり，慣れの効果と情動反応性の変化が混 同されている可能性がある (Kierniesky, Sick, \& Kruppenbacher, 1977; Selinger, 1977)。移動行動が情 動反応性によって抑制されるものとして考えると，こ の活動量の日間減少からは，テスト事態への慣れに伴 って情動反応性が高まることになってしまう。このよ うに，オープン・フィールド事態は情動反応性の測定 法としては種々の問題を有していることが指摘されて きた（Archer, 1973; 藤田，1975a）。

そこで，オープン・フィールド・テストよりすぐれ た方法として，ランウェイ・テストが考案された（藤 田，1975b)。このテストは，暗い出発箱と明るい走 路からなる装置を用い，出発箱に投入してからのラッ トの走路のぞき潜時，のぞき時間，走路への出発潜 時, 走路先端部分までの走行潜時, 走路上での移動 量, 排泄行動等を測定・記録するものである. 穴居 性, 夜行性というラットの生態学的特徵を考慮して考 案されたこのテストで, 出発潜時が短く, 走路上での 移動量が多い個体は情動反応性が低く, 出発箱にとど まる個体は情動反応性が高いとみなすことができる. 新奇なオープン・フィールド事態に投入されたラット は, すくみ反応とともに逃避反応を示す結果, 初期の 活動量が多く, 試行を繰り返すことにより逃避反応が 低下し，活動量も減少する。一方，ランウェイ・テス 卜事態では，走路において逃避反応が生じる可能性は 低く，活動量は日間増加を示すことになる (Miyamoto \& Fujita, 1981)。ランウェイ・テストにお ける種々の測度の中で通過区画数を指標とし，情動反 応性の異なる系統が選択交配されており, 種々の比較 研究によって情動反応性の指標としての妥当性が確認 されてきた（藤田・中村・宮本・片山・鎌塚 ・加藤, 1980 ; Fujita, Annen, \& Kitaoka, 1994).オープン・ フィールド・テストにおいて排便や排尿といった排泄 行動も情動反応性の指標として用いられてきたが （Hall，1934），身体的成熟が強く影響すると考えられ， 発達的変化を検討する場合には不適当であろう。

新奇事態に扔ける自発的行動の背景となる心理的概
る. 探索動因が環境内のある事物に対する接近傾向を さすのに対して, 活動性は環境要因に関係なく個体の 一般的活動水準をさす概念である。また情動反応性 は，個体の新奇環境に扔ける探索行動などの活動を抑 制すると考えられる。一方，慣れは新奇な環境への経 験とともに生じてくる生体の反応傾向の変化であり, 探索行動や情動的反応の低下をもたらす。

一方, 先行研究からはラットの情動反応性には性差 がみられ，一般的に雌の方が情動反応性が低いと報告 されてきたが (Archer, 1973), 情動反応性の性差が発 達段階のいつごろから発現してくるのかは検討されて いない，そこで，本実験ではランウェイ・テストを用 いて, 発達に伴う情動反応性の変化を検討する. 離乳 期, 離乳後期, 離乳期後, 成熟前期, 成熟期に該当す ると考えられる，20，30，40，60，90 日齢の雌雄ラ ットを対象とする. 実験 1 では, 各日齢でナイーブな 個体をテストする横断的方法による比較を行う。

また，離乳前の仔ラットにハンドリングなどの付加 的刺激作用を与えることによって成体時での情動反応 性は低下すると報告されてきたが（Daly，1973；宮 本，1986), 発達初期においては個体差はまだ不安定 な状態にあり，環境変化の影響を強く受けるとも゙考え られる。そこで実験 2 では，同一個体を繰り返しテス 卜する縦断的比較を行うことにより，特に離乳期後の ランウェイ行動がその時期に特有のものであるのか, あるいはそのころの個体差が持続されるのかどうかを 検討する。

\section{実験 1：ランウェイ行動の横断的比較}

本実験では，各日齢で異なる被験体を用いた横断的 な比較によって，ランウェイ・テスト事態における諸 反応の日齢に伴う変化を調べ, 情動反応性の発達的変 化を検討する. 離乳後の未成体期に情動反応性が低下 するならば，30-40日齢でランウェイへの出発潜時 が短くなり, 通過区画数が他の日齢よりも多くなるで あろう。 また，各日齢における日間変化からは，3040 日歯市, テスト初期から出発潜時が短く通過区画 数が多く，大きな変化を示さないが，他の日齢では日 間増加を示すであろう。

\section{方 法}

被験体 東海女子大学心理学研究室にて維持してき たウィスター系ラット，20-25 日齢雌 14 匹雄 17 匹, 30一-35 日齢雌 14 匹雄 15 匹，40 日齢雌雄各 15 匹，60 日齢雌雄各 15 匹，90日齢雌 14 匹雄 15 匹（80日齢 4 匹を含む)，可能な限り同腹仔を二つの日齢群に配分 し，計 16 リター 149 匹を用いた。雄 1 匹と雌 2 匹に より交配し，妊娠確認後，雌はオガクズを敷いたアク リル製繁殖ケージ $(30 \times 35 \times 17$ (高) $\mathrm{cm})$ に移した。 毎日午後 5 時に出産を確認し，仔を確認した日を 0 日 
齢とした. 20 日齢で離乳し，同性の集団（5-7 匹） で飼育した。なお室温は $25^{\circ} \mathrm{C}$ に設定した。照明は 7 時点灯 19 時消灯の 12 時間明暗サイクルであり, 餌と 水は自由摂取であった。

ランウェイ・テスト装置 藤田（1975b）に記述さ れた出発箱と走路からなる木製黒色の直線走路を用い た. 出発箱 $(20 \times 25 \times 45$ (高) $\mathrm{cm})$ と走路 $(20 \times 150 \times$ 45 (高) $\mathrm{cm}$ ）の間はギロチンドアで仕切り，このドア が上がると被験体は $7 \times 7 \mathrm{~cm}$ の出入口を通って走路 へ出入りすることができた. 走路には, 出発箱に近い 方から等間隔に A から E の 5 区画が灰色線によって 描かれていた。出発箱はふた付きで中は暗く, 走路は 照明されていた（約 $85 \mathrm{~lx}$ )。

手続き ランウェイ・テストは藤田（1975b）に準 じた方法で, 各日齢より1日 1 試行 (1 試行 5 分間), 連続 3 日間行った。ラットを出発箱に入れ，30 秒後 にギロチンドアを上げ，その後 5 分間にわたって被験 体の以下の測度を記録した。（a) 通過区画数，(b)の ぞき潜時，(c)のぞき時間，(d) 出発潜時，(e)E区画 潜時, (f) 排便数, ( $\mathrm{g}$ ) 排尿量 (3 段階評定). 5 分以内 に出発箱を出なかった場合, 各潜時は 300 秒とした。 なお実験日の前日に, 体重測定とマーキングを行い, 実験 3 日目に体重測定を行った。

\section{結果と考察}

ランウェイ・テストの各測度が, 情動反応性とどの ような関連をもつかを確認するために，ランウェイ・ テストの各測度の 3 試行合計值で因子分析（主因子 法，バリマックス回転）を行った ${ }^{1}$. 固有值 1 以上を 基準とし, 解釈のしやすさを考慮した結果, 通過区画 数 $(-.90)$, のぞき時間 $(-.61)$ に負の負荷量をも ち, のぞき潜時 (.77), 出発潜時 (.93), E 区画潜時 （.88）に正の負荷量をもつ第 1 因子（固有值 3.46）と 排便数 (.82) と排尿量 (.81) に正の負荷量をもつ第

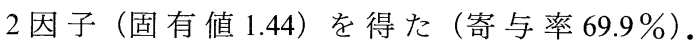

Whimbey \& Denenberg (1967) は, ラットのオープ ン・フィールド行動の因子分析を行った結果，“探索” と “情動反応性” は異なる行動次元にあり, 活動量は 情動反応性と探索に負荷が大きく, 排便量は情動反応 性に負荷が大きいと報告した。本実験の結果も 2 次元 構造になっているが，第 1 因子は走路のぞき反応や走 路上の移動を生じにくくする反応抑制的情動因子，第 2 因子は排便や排尿を増加する内臓反応的情動因子と 考えることができる．そこで以降，前者に負の負荷が 大きい通過区画数と正の負荷が大きい出発潜時を取り 上げ，後者に正の負荷が大きい排便数を取り上げるこ

1 時間データ (b-e) は短い方の頻度が多くなる $\mathrm{L}$ 字型の度 数分布を示したので，正規性を保証するために 1 を加えた後対 数変換を施した。
とにする。

各測度について日齢と性を要因とした 2 要因分散分 析を行ったところ (いずれも日齢 $d f=4,139$, 性 $d f=1,139$, 日齢 $\times$ 性 $d f=4,139)$, それぞれに有意 な日齢の効果が認められた。通過区画数は, Figure 1 に示すように 30 日齢で増加し, 40 日齢で低下する. その後 60,90 日齢では同程度レベルの反応が維持さ れた $(F=6.280, p<.001)$. 合計值を用いて Ryan 法 による多重比較を行ったところ，30日齢と 20，40日 齢の間に有意差がみられた $(M S E=2.218, d f=$ 144)。さらに, 出発潜時にも日歯の効果が有意であり (Figure 2, $F=6.487, p<.001$ ), 多重比較によると 30 日齢が 20, 40,60日齢よりも有意に短い $(M S E=$ $2.049, d f=144)$.また, 排便数は日齢に伴い増加した

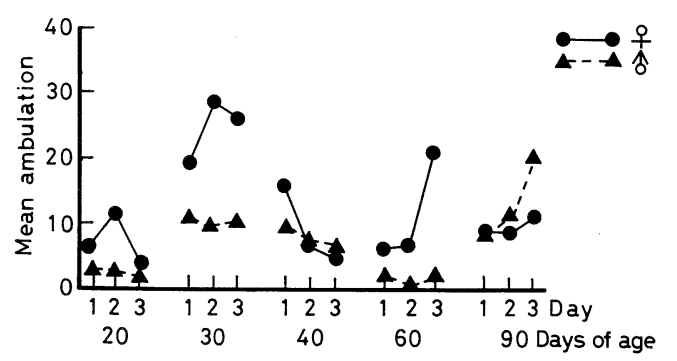

Figure 1. Mean scores of ambulation (sections traversed) on three days of the Runway Test in five different age groups.

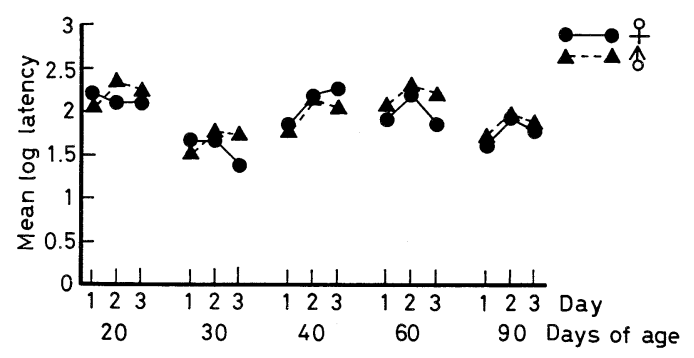

Figure 2. Mean scores of start latency (log $(x+1)$ transformed) on three days of the Runway Test in five different age groups.

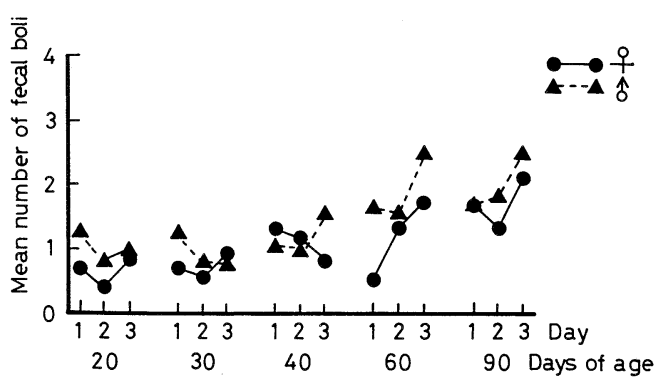

Figure 3. Mean number of defecations (fecal boli) on three days of the Runway Test in five different age groups. 
Table 1

$F$ values obtained by ANOVA (sex $\times$ days) on measures of the Runway Test at each age (AMB : ambulation,

$\mathrm{SL}$ : start latency, DEF : defecation, ${ }^{* *} p<.01,{ }^{*} p<$ $.05,{ }^{\dagger} p<.10$, blank cells mean non-significant.)

\begin{tabular}{|c|c|c|c|c|c|}
\hline age & factors & $(d f)$ & AMB & SL & DEF \\
\hline \multirow[t]{3}{*}{20} & $\operatorname{sex}$ & $(1,29)$ & & & \\
\hline & days & $(2,58)$ & & & \\
\hline & sex $\times$ days & $(2,58)$ & & & \\
\hline \multirow[t]{3}{*}{30} & $\operatorname{sex}$ & $(1,27)$ & & & \\
\hline & days & $(2,54)$ & & & \\
\hline & $\operatorname{sex} \times$ days & $(2,54)$ & $2.612^{\dagger}$ & & \\
\hline \multirow[t]{3}{*}{40} & sex & $(1,28)$ & & & \\
\hline & days & $(2,56)$ & $3.752 *$ & $5.320^{* *}$ & \\
\hline & sex $\times$ days & $(2,56)$ & & & \\
\hline \multirow[t]{3}{*}{60} & sex & $(1,28)$ & $4.445^{*}$ & & $5.297^{*}$ \\
\hline & days & $(2,56)$ & $2.906^{\dagger}$ & $3.429^{*}$ & $4.960^{*}$ \\
\hline & sex $\times$ days & $(2,56)$ & $2.790^{\dagger}$ & & \\
\hline \multirow[t]{3}{*}{90} & sex & $(1,27)$ & & & \\
\hline & days & $(2,54)$ & & & \\
\hline & sex $\times$ days & $(2,54)$ & & & \\
\hline
\end{tabular}

(Figure 3, $F=7.360, p<.001$ ), 多重比較からは 90 日 齢が 20，30，40 日齢より多く，60日齢が 20 日齢よ り多かった $(M S E=7.652, d f=144)$.さらに性差は, 排便数 $(F(4,139)=5.524, p<.05)$ に認められ, いず れも雄の方が多い.

次に各測度の日間変化を検討するために，各日齢ご とに日間と性の 2 要因分散分析を行った（Table 1). 日間の変化は全体的に性との交互作用として認められ た。40日齢において通過区画数（AMB）が日間減 少, 出発潜時 (SL) が日間増加を示した。 60 日齢で は出発潜時が 2 日目に増大し，排便数（DEF）は日 間増加を示した。また，性差が発現してくるのは 60 日齢で, 通過区画数 (雌>雄) と排便数 (雄 $>$ 雌) で あった。

これらの結果をまとめてみると，まず 30 日齢群が 出発潜時が短く, その身体的スケールに比して通過区 画数が多いことを指摘できる。排便は 60,90 日齢が それ以前よりも多く，全体的に幼若な個体で反応レ心゙ ルが低い傾向がみとめられる，以上の結果から，3035 日齢ころの発達段階においては情動反応性が一時 的に低下し，その後再び高まってそのレベルで安定す ると考无られる。すなわち，母親への依存から外的環 境の食物源へと移行し始める離乳期後 (Galef, 1981) には情動反応性が低下し, 新奇な環境においてより活 発な探索行動を示すことになる。一方，20日齢群は
新奇場面において活動量が少ないが, 実験室飼育条件 での強制的離乳という，環境の大きな変化を受けたこ とによるとも考えられる。

\section{実験 2：ランウェイ行動の縦断的比較}

実験 1 で横断的方法により日齢間のランウェイ行動 を比較した結果, $30-35$ 日齢の通過区画数が大きく 突出し, 40 日齢で減少した後, そのレベルを保つこ とがわかった。こうした情動反応性の低下が生じる離 乳直後の時期は, 成体時と比較すると情動反応性の個 体差が不安定な状態にあるとも考えられる．藤田他 （1980）は，ランウェイ・テストの信頼性を検討する ために，60，90，120日齢と 3 回のランウェイ・テス 卜を行い, 日齢間の相関係数を求めたところ, 雌では .62-.65 とやや低いものの, 雄で .86-.92 とかなり高 い値を得ている。しかし，それ以前は不明である。ま た実験 1 では, 性差が顕著に現れるのは 60 日齢から であり，雌の方が低情動であることが認められた。本 実験では，さらに幼若な各日齢で同一個体を繰り返し テストする緃断的比較を行うことにより，特に離乳期 前後のランウェイ行動がその時期に特有のものである のか，あるいはそのころの個体差が持続するのが，ま たそれには性差が関係してくるのかを検討する。この 縦断的比較においては, テスト事態へ繰り返しさらさ れることによって情動反応性が低下し, 抑制されてい た移動量は日間増加を示すと予測される。

\section{方 法}

被験体 東海女子大学心理学研究室にて交配し出生 したウィスター系ラット4リター, 雌 24 匹雄 16 匹, 計 40 匹を用いた。

装置 実験 1 と同じ.

手続き $20 ， 30 ， 40 ， 60 ， 90$ 日齢より，1 日 5 分間 で連続 3 日間のランウェイ・テストを繰り返し行い, 各測度の縦断的な日齢間比較を行った。

\section{結果と考察}

実験 1 と同様, 各測度について日齢と性の 2 要因分 散分析を行い（いずれも性 $d f=1,38$, 日齢, 性 $\times$ 日 齢 $d f=4,152)$, 必要な場合には Ryan 法により日齢 間比較を行った. Figure 4 に示すように, 通過区画 数については 20 日齢が他の日齢よりも少なく，30日 齢が 60, 90 日齢よりも少ない $(F=87.113, p<$ .001)。また, 出発潜時には日齢の主効果が有意であ り $(F=124.946, p<.001), 60$ 日齢まで日齢に伴い短 縮した (Figure 5).排便数では雄が雌よりも多く $(F=15.026, p<.001)$, 日齢の主効果は有意であった が $(F=2.681, p<.05)$, 多重比較の結果は群間の差が 不明であった（Figure 6)。なお 60，90 白齢の雄に走 路上での連続排尿が頻繁に出現した（3 日間のテスト 
Table 2

$F$ values obtained by ANOVA (sex $\times$ days) on measures of the Runway Test at each age (AMB : ambulation, $\mathrm{SL}$ : start latency, DEF : defecation, ${ }^{* *} p<.01,{ }^{*} p<$ $.05,{ }^{\dagger} p<.10$, blank cells mean non-significant.)

\begin{tabular}{|c|c|c|c|c|c|}
\hline age & factors & $(d f)$ & AMB & SL & DEF \\
\hline \multirow[t]{3}{*}{20} & $\operatorname{sex}$ & $(1,38)$ & & & $5.397^{*}$ \\
\hline & days & $(2,76)$ & & & \\
\hline & sex $\times$ days & $(2,76)$ & & & \\
\hline \multirow[t]{3}{*}{30} & $\operatorname{sex}$ & $(1,38)$ & & & $14.134^{* *}$ \\
\hline & days & $(2,76)$ & $21.873^{* *}$ & $21.547^{* *}$ & \\
\hline & sex $\times$ days & $(2,76)$ & & & \\
\hline \multirow[t]{3}{*}{40} & sex & $(1,38)$ & & & \\
\hline & days & $(2,76)$ & $11.730^{* *}$ & $8.011^{* *}$ & $5.148^{* *}$ \\
\hline & sex $\times$ days & $(2,76)$ & $3.683^{*}$ & & $6.374^{* *}$ \\
\hline \multirow[t]{3}{*}{60} & sex & $(1,38)$ & $7.250^{*}$ & & $7.426^{*}$ \\
\hline & days & $(2,76)$ & $5.323^{* *}$ & $3.762^{*}$ & $8.817^{* *}$ \\
\hline & sex $\times$ days & $(2,76)$ & & & $11.599 * *$ \\
\hline \multirow[t]{3}{*}{90} & sex & $(1,38)$ & $9.758 * *$ & & $2.990^{\dagger}$ \\
\hline & days & $(2,76)$ & & & \\
\hline & sex $\times$ days & $(2,76)$ & & & \\
\hline
\end{tabular}

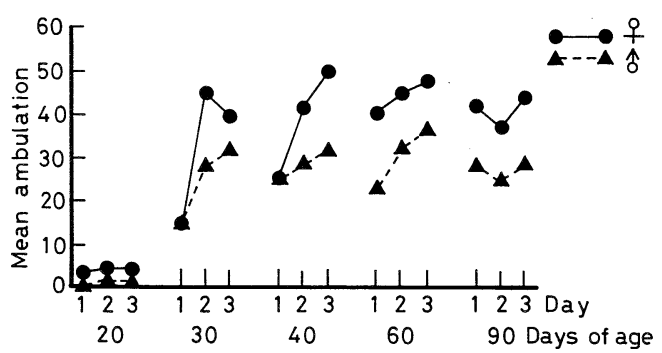

Figure 4. Mean scores of ambulation (sections traversed) on three days of the Runway Test at five different ages.

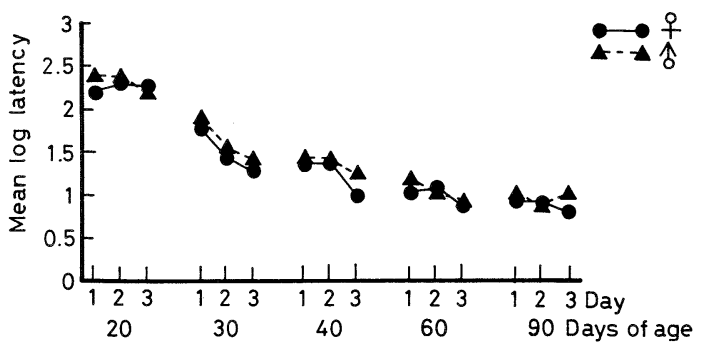

Figure 5. Mean scores of start latency $(\log (x+1)$ transformed) on three days of the Runway Test at five different ages.
で反応を示した雄個体の割合，60日歯 $62.5 \% ， 90$ 日 齢 $56.2 \%$ ).

次に各日歯ごとに各測度について日間と性の 2 要因 分散分析を行った（Table 2). 日間変化についてみる と，20日齢では排便数が日間増加傾向を示した。 30 日歯では第 2 日目に通過区画数が増加し, 出発潜時が 短縮した。また，40日齢においても通過区画数が増 加し, 出発潜時が短縮した。ささに排便数の日間減少 が雄で顕著であった。 60 日齢でも通過区画数は日間 増加, 出発潜時が短縮, 排便数は日間減少を示し, 特 に雄に顕著であった。一方 90 日齢は大きな変化を示 さなかった，以上のように各測度の日間変化からは， 20 日齢において活動量が少なく日間変化が明白でな いこと，30，40 日齢は日間増加が顕著であるが，90 日歯では漸近值レベルとなっており，移動活動も日間 変化を示さなくなる.

次に，性差については，20日齢では排便数のみに 雄が雌よりも有意に多く，30日歯も排便数で雄が多 い.また 40 日齢では雄に走路上での連続的排尿が出 現した。さらに，60，90日齢では雌の方が通過区画 数が多く, 雄は排便数, 走路での排尿が多い.

通過区画数について日齢間の積率相関係数を算出し たところ，継続する日齢間では比較的高い正の相関を 示したが $(20-30$ 日歯 .39，30-40 日齢.74，40-60 日齢 .80，60-90日歯 .62), 間隔が離れると徐久に低 下し（20-60日齢.22，30-90日齢.23），20日齢と 90 日齢とはほとんど無相関であった（.05）。60日齢 と90日齢との相関は, 藤田他 (1980) の報告と比較 するとかなり低めであった，20-30 日歯間の相関が 特に低いことから，20日歯仔は強制的離乳の生理的 影響が大きく，環境の影響を受けて個体差が変動しや すいことを示唆するとともに，情動反応性のデータと してはふさわしくないと考えられる。一方，30日龄 以降比較的高い正の相関がみられたことから, 個体差 はかなり安定し一貫したものとなっているといえる。 すなわち, 離乳期直後の情動反応性の低下は各個体の レベルで生じると考えられる。

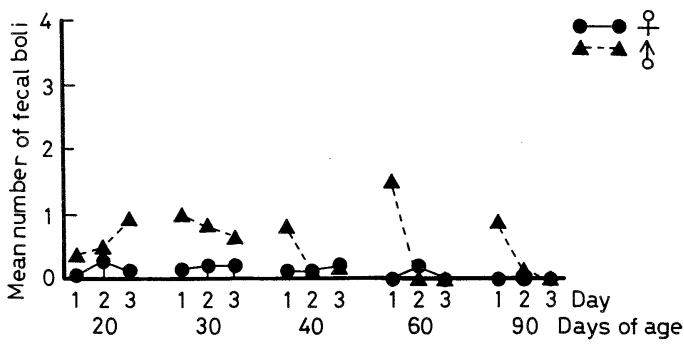

Figure 6. Mean number of defecations (fecal boli) on three days of the Runway Test at five different ages. 


\section{総合的考察}

実験 1 のランウェイ・テストの横断的比較からは, 30-35 日齢で出発潜時が短縮し, 移動量が増加して おり，情動反応性が低下しているといえよう。これを 実験 2 の結果と比較すると, 通過区画数については, 30 日歯令で縦断的比較群（実験 2）は横断的比較群（実 験 1）よりも多い傾向を示し，40 日齢以降はこの傾向 が一貫している。また，縦断的研究の各測度の日間変 化からは，30，40 日齢は日間増加が顕著であり，テ スト事態に繰り返しさらされることによる情動反応性 の低下を反映している。そして 60，90 日齢では移動 活動も漸近值に達し，日間変化を示さなくなる。

Galef (1981) は，ラットの母仔関係のアナロジー として宿主-寄生者関係を取り上げ，離乳後の未成体 期を巣外での食物摂取を母親とともにする共卓関係に あるとし，食物源の定位や食物選択の情報をこの時期 に獲得すると報告した。離乳後に情動反応性が低下し 巣穴から巣外へ頻繁に出ることは，その後の食物採集 や貯蔵を容易にするであろう。巣穴と巣外をシミュレ ートしたランウェイ・テスト事態で認められた情動反 応性の低下は, 離乳後の未成体ラットの個体発生的適 応となっていると考えられる (Alberts, 1987).

一方前述のように，20日齢ラットの低活動と 30 日 齢の高活動は, 強制的離乳という操作の影響として次 のような解釈も可能である. すなわち, 通常は母仔の 相互作用が続いている 20 日歯での母仔分離は, 仔を 生理的に衰弱させ，体重も一時的に低下させる。それ から回復し,さらに成長するために，30日齢ころに 飢餓欲求が強まり, 飭を求める探索行動が強まる。し かし, 40 日齢以降は飢餓欲求, 活動量も比較的低レ ベルで安定する.この可能性を検討するためには，母 仔分離を行わない条件で，20，30日歯でのランウェ イ・テストを行う必要があろう。

オープン・フィールド・テストで情動反応性の指標 として有効とされていた排便や排尿については, 横断 的比較からは幼若な個体では全体的に少なく，60,90 日齢では日間増加を示した。さらに縦断的研究では, 排便反応は 40 日齢以降の雌ではほとんど認められず, 雄でも第 1 日目に出現したのみであった。排尿につい ては，60，90日歯の雄で特に反応レベルが高くなっ た. 行動観察によると, 60, 90 日齢ラットによる排 尿行動は, 雌や幼若な雄の行動とはいくつかの点で異 なっていた，第一に，腹部を低くした，這うような特 有の姿勢を示すこと，第二に，移動しながらの連続的 排尿が多かったことである. Peden \& Timberlake （1990）は，成体ラットによる慣れた事態での体幹に よるマーキングは雄の方が多いが，排尿によるマーキ ングには性差はないことを報告している. 本実験での
90 日齢での慣れた事態で生じることから, 情動的排 尿というょりは，むしろなわばり性のものではないか と思われる，以上より排便や排尿は，情動的側面とと もに社会的側面や内臟諸機能の成熟をも反映している といえよう.

最後に, ラットという種の発達における離乳後の情 動反応性の一時的低下の意味を考察したい. Meaney \& Stewart（1981）は，離乳後未成体期における初期の 遊び攻撃は近接する 2 個体間で同時に発現するのに対 して，26-30 日齢では特定の個体が攻撃を開始する ようになると報告した。さらに，40日齢までは遊び 攻撃に優位-服従の関係はみられないが，45 日齢以降 には優位個体が固定していると述べている。本研究か らは, 離乳期の情動反応性は変動しやすく, 30 日歯 ころからは比較的安定することが示唆されたが，情動 反応性の相違が社会的行動の個体差発現の基礎となっ ているのかもしれない．また，物理的環境に対する探 索行動は情動反応性により抑制される。巣穴から出て 初めて食物採集を開始する離乳直後の未成体期に一時 的に情動反応性が低下することは，こうした巣穴付近 の探索行動を促進すると考えられる.今後, ランウェ イ・テスト以外の指標によってこの現象を確認ずると ともに, 他の社会的行動や学習行動との関連を検討す ることが必要であろう。

\section{引用文献}

Alberts, J. R. 1987 Early learning and ontogenetic adaptation. In N. A. Krasnegor, E. M. Blass, M. A. Hofer \& W. Smotherman (Eds.), Perinatal development: A psychobiological perspective. Orlando: Academic Press. Pp. 11-37

Annen, Y. 1985 Relationship between emotionality of intruders and aggressive behavior of residents in rats. Japanese Psychological Research, 27, 119-124.

Archer, J. 1973 Tests for emotionality in rats and mice: A review. Animal Behaviour, 21, 205-235.

Bauer, R. H., \& Duncan, D. L. 1975 Differential effects of d-amphetamine in mature and immature rats. Physiological Psychology, 3, 312-316.

Bronstein, P. M. 1972 Open-field behavior of the rat as a function of age. Journal of Comparative and Physiological Psychology, 80, 335-341.

Bronstein, P. M. 1973 Replication report: Age and open-field activity of rats. Psychological Reports, 32, 403-406.

Campbell, B. A., \& Marby, P. D. 1972 Ontogeny of behavioral arousal: A comparative study. Journal of Comparative and Physiological Psychology, 81, 371-379.

Daly, M. 1973 Early stimulation of rodents: A critical review of present interpretation. British Journal of Psychology, 64, 435-460. 
藤田 統 1975a Open-field 行動とは何か 東京教 育大学教育学部紀要, 21, 45-51.

藤田 統 1975b ラットの情動反応性の指標として のランウェイ・テストにおける諸反応の行動遺伝学 的分析：I 表現型変異と子-親回㷌に基づく遺伝率 推定值 心理学研究, 46, 281-292.

藤田 統 - 中村則雄 - 宮本邦雄・片山尊文・鎌塚正 雄・加藤 宏 1980 選択交配により作られた高 ・ 低情動反応性系ラットの行動比較 筑波大学心理学 研究, 2, 19-31.

Fujita, O., Annen, Y., \& Kitaoka, A. 1994 Tsukuba high- and low-emotional strain of rats (Rattus norvegicus): An overview. Behavior Genetics, 24, 389415.

Galef, B. G., Jr. 1981 The ecology of weaning: Parasitism and achievement of independence by altricial mammals. In D. J. Gubernick \& P. H. Klopfer (Eds.), Parental care in mammals. Yew York: Plenum Press.

Hall, C.S. 1934 Emotional behavior in the rat. I: Defecation and urination as measures of individual differences in the emotionality. Journal of Comparative and Physiological Psychology, 18, 385-403.

Iso, H., Brush, F. R., Fujii, M., \& Shimazaki, M. 1988 Running-wheel avoidance learning in rats (Rattus norvegicus): Effects of contigencies and comparisions of different strains. Journal of Comparative Psychology, 102, 350-371.

Kierniesky, N., Sick, T., \& Kruppenbacher, F. 1977 Open-field activity of albino rats as a function of sex, age and repeated testing. Psychological Reports, 40, $1255-1260$.

Lanier, L. P., \& Issacson, R. L. 1977 Early development changes in the locomotor response to amphetamine and their relation to hippocampal function. Brain Research, 126, 567-575.

Meaney, M. J., \& Stewart, J. 1981 A descriptive study of social development in the rat (Rattus norvegicus). Animal Behaviour, 29, 34-45.

宮本邦雄 1986 ラットの母親行動及び情動反応性に 及ぼす離乳前ハンドリングの効果 動物心理学年 報, 36, 65-75.

宮本邦雄 1993 ラットにおける貯蔵行動の発達と情 動反応性 動物心理学研究, 43, 42 .

Miyamoto, K., \& Fujita, O. 1981 The situational determinants of open-field behavior in JCR/JCL mice. Japanese Psychological Research, 23, 169-173.

中村則雄・阿部 勲・藤田 統 1978 高・低情動反 応性系ラットの行動比較：2-ーオープン・フィー ルド行動と貯蔵行動—— 心理学研究, 49, 61-69.

Peden, B. F., \& Timberlake, W. 1990 Environmental influences on flank marking and urine marking by female and male rats (Rattus norvegicus). Journal of Comparative Psychology, 104, 122-130.

Satinder, K. P. 1981 Ontogeny and interdipendence of genetically selected behaviors in rats: Avoidance responses and open field. Journal of Comparative and Physiological Psychology, 95, 175-187.

Selinger, D. L. 1977 Effects of age, sex and brightness of field on open-field behaviors of rats. Perceptual and Motor Skills, 45, 1059-1067.

Spear, L. P., \& Brake, S. C. 1983 Periadolescence: age-dependent behavior and psychopharmacological responsivity in rats. Developmental Psychobiology, 16, 83-109.

Valle, F. P., \& Bols, R. J. 1976 Age factors in sex differences in open-field activity of rats. Animal Learning \& Behavior, 4, 457-460.

Whimbey, A. E., \& Denenberg, V. H. 1967 Two independent behavioral dimensions in open-field performance. Journal of Comparative and Physiological Psychology, 63, 500-504.

-1996.5. 31 受稿, 1997.5.10 受理—— 